$\mathrm{Oz}$

Volume 31

Article 3

$1-1-2009$

\title{
LeapFrog Residence
}

Katherine Lawrence

Charlie Weiss

Follow this and additional works at: https://newprairiepress.org/oz

(c) $($ ) $\Theta \Theta$

This work is licensed under a Creative Commons Attribution-Noncommercial-No Derivative Works 4.0 License.

\section{Recommended Citation}

Lawrence, Katherine and Weiss, Charlie (2009) "LeapFrog Residence," Oz: Vol. 31. https://doi.org/ $10.4148 / 2378-5853.1462$

This Article is brought to you for free and open access by New Prairie Press. It has been accepted for inclusion in Oz by an authorized administrator of New Prairie Press. For more information, please contact cads@k-state.edu. 


\section{LeapFrog residence}

interview with Charlie Weiss \& Katherine Lawrence

Could you tell us about yourselves and your project?

[Charlie] I studied environmental architecture in college, and though I ended up with a degree in environmental economics, I have followed new sustainable-building developments closely ever since. We built our first house together in 1993 , working with a residential designer (not officially an architect) who asked us to write an essay about what we wanted in a house. She translated our very clear written picture into a house that in many ways is similar to the LeapFrog homes.

Where did the idea for the LeapFrog House come from?

Our first house incorporated a number of "green" features: radiant heat, solar hot water, natural materials, efficient appliances and fixtures. Before we'd finished we were already dreaming of building again when more and better sustainable products and systems became available. In 1999 we had a chance to buy a nearby property from a friend: a double lot with a dilapidated house on it. Our idea was to divide the lot in two (to the minimum zoned lot size) and build two sustainable homes, and to include an apartment in each to maximize the number of residents.

Where did your interest in sustainability come from?

Charlie's 1970s education; Katharine's depression-era thrifty father and a 8 mom who worked in solar and

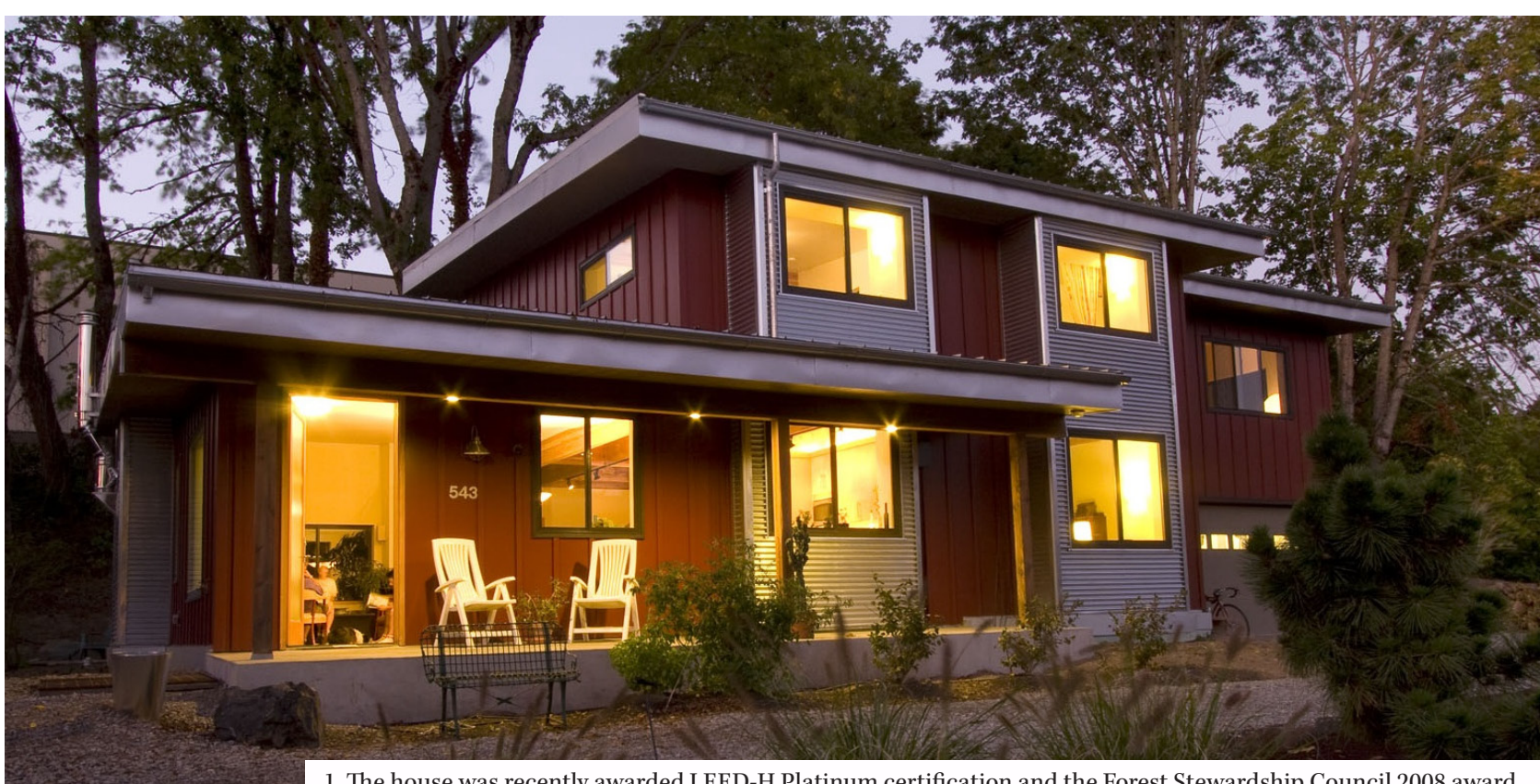

energy conservation; ecology- and conservation-minded families growing up in the Pacific Northwest with abundant access to nature; and living in a town with strong greenbuilding ethics and resources.

Why are your houses more ecologically sensitive than those designed by many professional architects?

Topush the limits. Charlieis a researcher by nature who's driven to learn. $\mathrm{He}$ gathered the necessary information and contacts to push virtually every dimension of sustainability in this project beyond what's expected. Many of those dimensions (like the potable rainwater system) are not well understood in the architecture world and residential projects rarely have the budgets to hire engineers and also support their learning process. So this project emerged from what we could learn on our own.

We let LEED and our best judgment guide us. We received word last week that the houses have finally received LEED-H Platinum certification: 107 points for our house, 99 for the other (the difference is solar panels - we installed them on our house and wired the other house for future installation; it was a cost and tax credit decision). In every way possible, we tried to meet or exceed the sustainability of what was known at the time - which put us pretty far ahead relative to the requirements set forth by the USGBC.

Didyou consult with an architect, design professional, or anyone in the building trade? Why or why not?
We worked with a residential designer. Although we had done most of our own planning, we wanted to add her experience in making light, livable spaces, and to produce finished plans.

We were challenged and inspired by the ongoing collaboration with design details, the choice of insulation and other materials, and with our plumber and heating contractor to pull together our innovations for using a ground-source heat pump to heat both domestic hot water and the space.

Could you describe the process from design to completion?

The "design" began in the mid-1990s based on our experience with our first house (combined with having our builder on matters like the roof 
lived in and visited many good, and bad, examples of residential design). Katharine spent many hours pouring through stacks of library books of plans and design ideas, defining and refining efficient, flexible floor plans. Charlie attended green-building workshops, made connections with people in the industry, and spent many months online.

We held an eco-charrette in 2004 attended by public- and private-sector green-building experts who helped shape our thoughts on design, systems and materials. We made a couple of false starts with architects before a lucky break reconnected us with the designer who worked with us on our first house, Kathy Kremer. She had experience designing solar houses in the 1970s, and helped us to incorporate our collection of ideas into a livable, buildable whole. The design process evolved further with our builder, Green Hammer Construction. Both the owner, Stephen Aiguier, and our project manager, Alex Boetzel, brought years of green-building experience to our project. Alex had started his career in his native Germany, in some ways years ahead of the U.S. in terms of efficient, sustainable building. We made many decisions during the building process that were not good for the short-term budget but valuable in the long term.

Could you elaborate a little more on the eco-charette?

When Charlie tells the story about the process of planning for and building our house he tells about the charrette.

He then says, "Our goal was to collect all the ideas for a great house, and then narrow them down to a prioritized list. In the end, almost everything (and more) made it onto the list of what to incorporate in this project, as if we forgot the prioritizing step." And that really set the tone for the project: to do everything we could to reduce the footprint.

Charlie and his business partner, John Thomas, ran the meeting; as marketing consultants, they are pros at running focus groups, brainstorms and charrettes.John also had the advantage of having studied environmental architecture at ASU.

Lawrence/Weiss Eco-charrette 9 April 2004

Meeting Objectives

Our primary objective for this eco-charrette is to capture ideas from diverse expertise in collaborative setting, to create breakthrough efficiency and value for a new class of home. Within this context, we will work to identify and prioritize strategies and materials that support the project's goal of building as green as a mid-market price point will allow.

The Brainstorm and Prioritization portion of the meeting will be organized around the five LEED categories, emphasizing specific subsets of each to more efficiently use our limited time:

Site (largely defined by existing terrain and vegetation, footprint)

Energy (envelope, HVAC/DHW)

Water (rainwater capture and use)

Materials and resources (exterior and structural, including roofing, siding, structure, windows)

Indoor air quality (interior materials and finishes, HVAC issues)
Your Prep:

Y

Please bring at least two or three idea in your areas of expertise and interest that would help make this an easily replicated breakthrough project and approach. Also, as you introduce yourself to the group. please explain what unique opportunities and value you see in this project.

Proposed Agenda:

12:00 Welcome and Introductions

12:20 Review the project and its parameters

01:00 Brainstorm

02:30 Break

02:45 Prioritize and integrate

04:15 Discuss next steps

Invitees:

Linda Barnes and Matthew Dalla Corte (Robertson Merryman Barnes Architects, the project's architects at the time)

Mike O’Brien and Greg Acker (green building specialists from the Portland Office of Sustainable Development) Duane Woik

(Earth Advantage, the organization that processes LEED-H in the region)

Dave Brunkow (CH2M, an engineer and a builder)

Doug Boleyn (solar engineer from Cascade Solar)

Kacia Brockman (solar expert from Oregon Energy Trust)

Cecil Smith (Healthy Homebuilder)

Dan Cote (green building consultant, Conservation Services Group)

Charlie Stephens (Oregon Department of Energy) Emily Hughes (Portland Bureau of Development Services)

Two invitees who couldn't attend that day were Portland's leading green homebuilder and the staff scientist from a local bank.
What have you learned so far?

As "amateur" builders, we've learned that we, Charlie and Katharine, could have used more design expertise on this project, as well as production expertise. Is there ever enough?) We've continued to learn more about specific aspects of our project, like the rainwater system, the tradeoffs in some of our materials choices.

We now know that we should have insisted that the plans were in $\mathrm{CAD}$ and pressed for nearly every detail to be worked out fully in advance. As it was we had line drawings and our builder's best guess at what it would take to build. We sailed over budget by about $40 \%$, which was insane from a cost perspective. But we were also trying to build prototypes, learning labs, from which we could move on to build more frequent and better informed designs. Higher costs are expected from a prototype exercise. In reality, though, they're a bit inconvenient.

A more tactical example of our learning process is our countertops. We agonized over what material to use for kitchen counters, and eventually came around to wanting to use a local wood. Pacific madrone makes up into a really beautiful butcher-block. The wood has widely variable, light-to-dark rich reddish-brown tones, and is harder than maple. Sounds good so far... Now that we have the madrone in place, we've learned it wasn't necessarily a great choice for that application. The wood is moving (raising seams, adding texture, expanding and shrinking), plus we haven't been able to get a satisfactory natural finish on it that 
really resists water and stains.

Another big one is the rainwater system. Its state-of-the-art UV sterilizer is extremely effective at making safe water, but it uses 200 Watts/hour Left on $24 / 7$, that would be about $1 / 3$ of our annual power bill. Not good. It has a long warm-up time, so ondemand doesn't work, either. We're still working with the supplier to find a way to program a solution to that challenge. We also discovered that the large hickory tree overhanging our roof leaches tannins into the rainwater, which pass through our filter and UV at full strength. Tea anyone? We are working to find charcoal filters that will strip out the tannins without reducing our water pressure too much.

How has the process changed as you moved from building your own house to building houses for others?

We built two LeapFrog houses simultaneously, one for ourselves and one to sell. With a few exceptions, the houses are identical. Our own house includes a 600 SF apartment over the garage. In the spec house we opted to leave that space unfinished to allow a buyer some flexibility in using that space. Our house includes

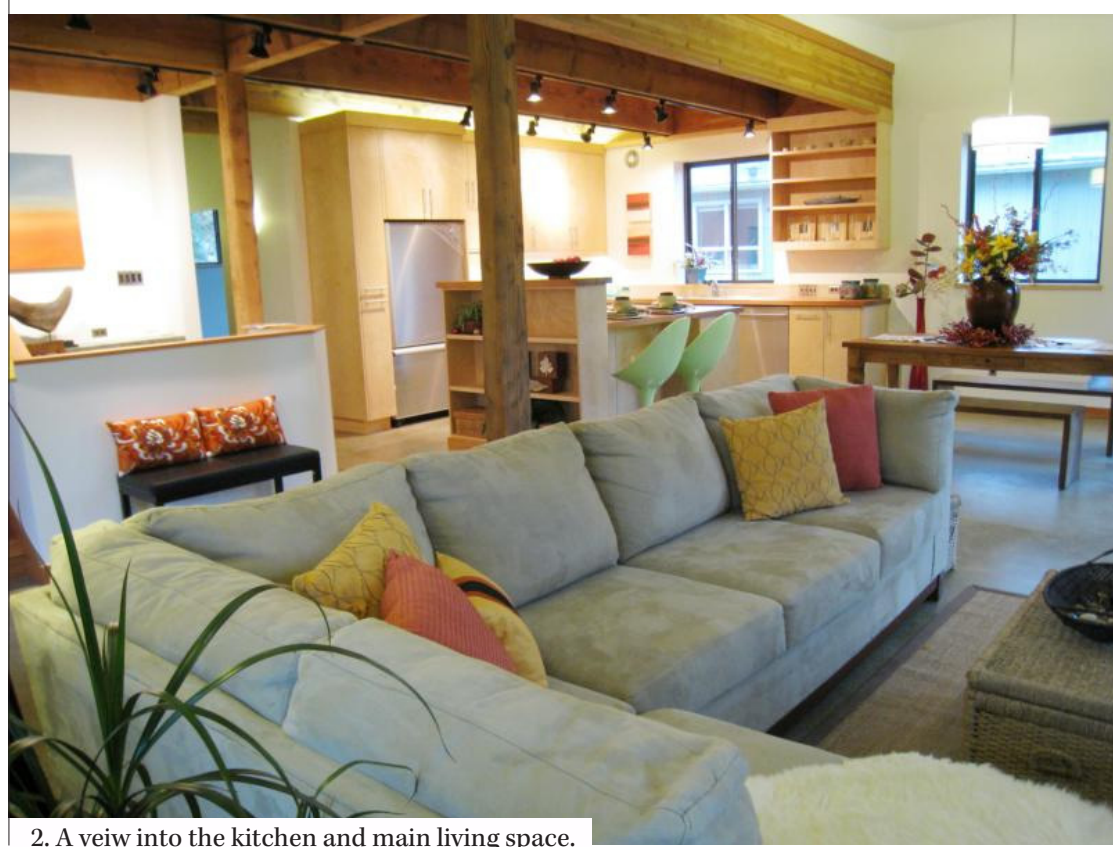

5 some rooms of with Ikea cabinets, but in the spec house we chose to keep it "pure" by using all local, Forest Stewardship Council (FSC) -certified wood cabinetry, shelving and poured-in-place high fly-ash concrete countertops.

As we were wrapping up our project a client of Green Hammer's bought a set of our plans and modified them for their own project. Green Hammer incorporated much of what they learned from the LeapFrog project in that project, and several others they've done since. To date, we haven't built any more LeapFrog houses, due largely to market and timing issues.

How does the energy use of your previous house compare to your new house?

The old house is similar in square footage and configuration (2 story, apartment above garage), in its hydronic heat distribution, its location (across the street), its orientation (big side faces south), in people living in it (the same 4-5 of us), and in our habits (both families are tight with water, lights, and the thermostat). It's different in that it has a gas (a boiler for heat and hot water, vs. our heat pump, two clothes dryers and two cooktops) and the envelope is pretty much to current code, vs. ours which is well beyond code. December was an unusually cold month here. The old house energy bills (gas and electric) were just short of $\$ 400$ for the month (and that's a house that was and perhaps still is high-performance relative to the standard home). Ours was $\$ 174$ (all electric, with virtually no solar generation that month).

Have you encountered any opposition or support? Where does it come from?

We experienced only minor challenges (though significant delays) working with the City of Portland.

Potable rainwater system permit: The first reviewer who handled our potable rainwater-system permitting was woefully ignorant about the topic. This wouldn't have been a problem had he been willing to work with us and be open to learning. Eventually, an über-inspector was assigned to sort things out. This caused a 6 -week delay.

Tree-removal permits: We spen (and lost) a lot of time dealing with tree issues. The City is trying to preserve mature trees for their positive role in stormwater management and urban habitat. But their process makes it an extra challenge to remove them. In our last tree tangle, we were given the City's first permit to remove trees "for solar access".

Stormwater permits: Despite our 6,000 gallons of rainwater storage capacity ( for each house) on this 20,000 square-foot lot, the City required us to build sand filters for stormwater detention. They are sized according to the impervious roof area to slow the release of rainstorms from the site. With our storage tanks, we felt this was redundant detention, but the City didn't agree.

Overall, we sawalot of administrative delays that required us to educate the planners and inspectors.

Mostly we had overwhelming support (and some heartfelt thanks) from the wide range of people and organizations who touched this project.

We have given tours of the project to nearly 1,000 people, of all backgrounds and interests, including energy-efficiency experts from utilities and consulting firms, construction professionals, government green-building officials, water resource specialists, other officials, realtors, aspiring green builders and homeowners looking for inspiration. People love what we've done and appreciate learning from our experience.

Many people have toured the LeapFrog project because they want to build or remodel their own home, rather than buy an existing one. We hope the support will extend soon to someone buying the second house. What we've seen so far doesn't really encourage building green on spec. Is this because buyers just aren't used to seeing - or evaluating - extremely green homes?

It was much more challenging to build these houses in 2007-8 compared to our experience building in 1994. Back then, it seems everything was dramatically simpler - permitting, codes, choices of materials and systems.

In 1993, our builder easily pulled the permits himself for the whole project at one time. In contrast, permitting for the LeapFrog project was a complex and demanding effort throughout the construction process. Photovoltaic panels weren't economically feasible back then, and there were no incentives. FSC was founded in 1993 and the USGBC in 1998. "Green” wasn't even used to describe building (except, our former builder recently smirked, as a paint color).

What is the Internet community like in comparison to "the industry"?

The Internet community varies enormously in terms of the credibility and experience of those offering 
opinions, systems, solutions to various green problems and opportunities. As a whole, I would not claim it's reliable. But there are some worthy sources out there. The challenge for me was to know enough to see value; I was often lower on the learning curve than I thought.

Could anyone easily design and build their own inexpensive sustainable house?

From our perspective, buying a completed green home would save a lot of heartache and money, compared to building a new one. For us, this project was a full-time job for two people for at least a year and a half. If peace of mind is an issue, and you want a green home, buy don't build. We did a lot of trailblazing here, which is way more costly and time-consuming.

In one sense it's getting easier all the time. For us, prefab is next. There's really nothing that couldn't be done equally as well or better in a prefab house. It's good to see more prefab options, which makes building far more predictable and affordable. On the other hand, we added complication to our project with our desire to push things as far as we did, and to work out so many details along the way. We wanted it to be a learning lab, a prototype to inspire people, including ourselves, to do more. The economy's challenges, combined with the environment's (energy, and water and other materials resources) may inspire - or force - more people to build green in the future.

We've made it available to very large numbers of people to tour and we've answered the hundreds of questions we've been asked as honestly as we can. We really want there to be more green building for all the reasons that it's such a great and necessary thing for now and the future, and sharing with others seems a way to help more people do that. Yes, the project has fulfilled those ambitions, perhaps at the cost of inspiring people to build or remodel their own homes rather

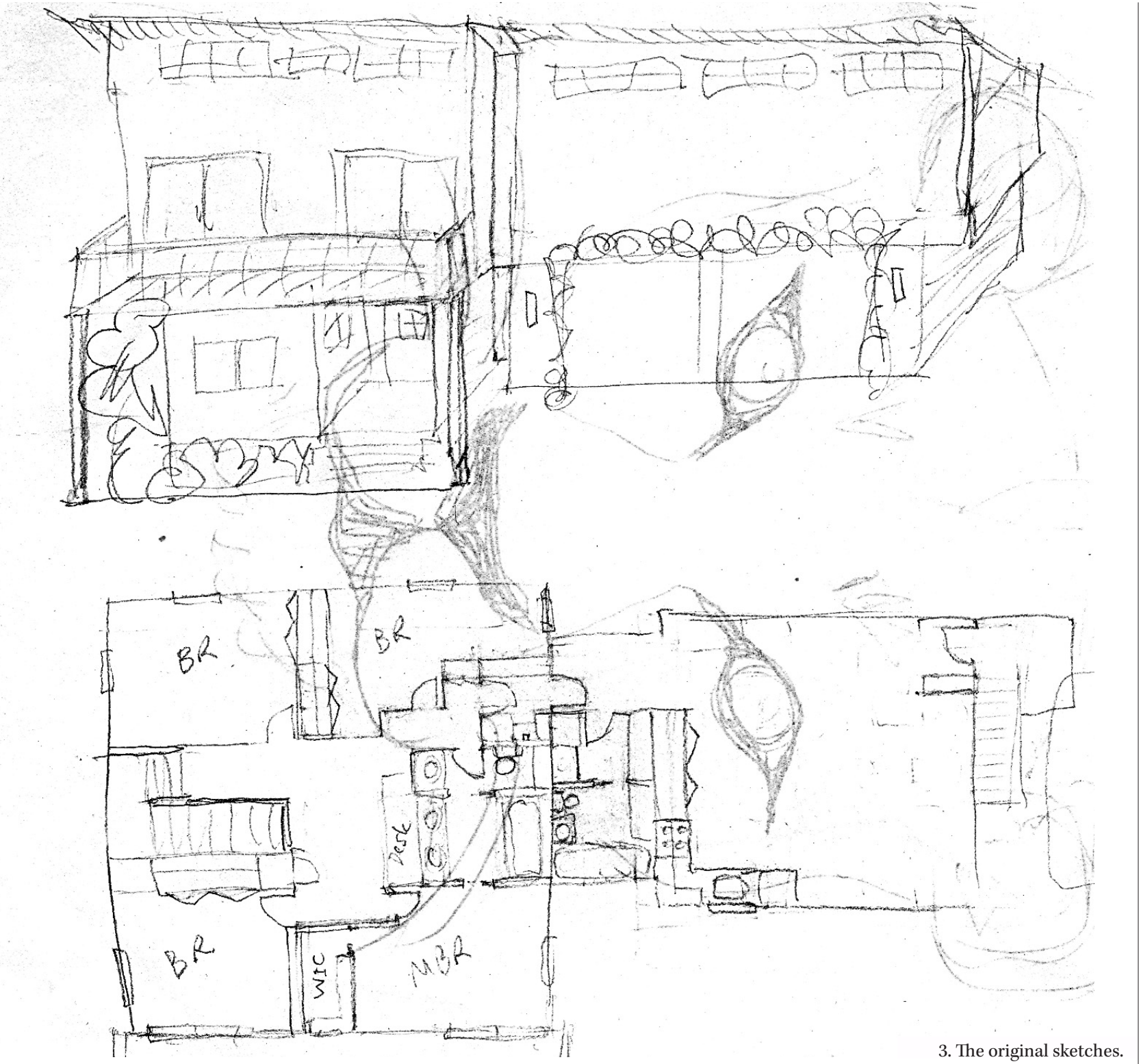

than buying the one we built!

We sold our floor plans to one of Green Hammer's clients. They only made a few minor changes to the plans and will be incorporating much of what we learned about systems and materials.

Given your ability to design and build these houses, do we need professional architects anymore?

From one perspective, yes: we could've benefited from more input and thinking-through details from an architect on this project. Mainly the ability to detail the whole project in $\mathrm{CAD}$ before getting bids, and we'd definitely use an architect or designer for any future projects for that reason. From another viewpoint, buying a welldesigned prefab might not engage an architect directly with the buyer, bu the architect's contribution to the form, given stricter parameters for function (efficiency), may be even more important.

\section{Anything else you would like to add?}

A lot of what we did in the LeapFrog houses reached past what currently "pencils out”. Based on current rates and availability, water and energy systems look expensive, and have unpalatably long payback times. But we felt strongly that water and energy will become scarce rapidly well within the lifespan of these homes, and the owners will be relieved to have high resource efficiencies and high performance built in. 